\title{
Zika Virus and Perinatal Outcomes: Beyond the Myth
}

\author{
Naira R Matevosyan* \\ Department of Surgery, New European Surgical Academy, Emory University, USA
}

${ }^{*}$ Corresponding author: Naira R Matevosyan, Department of Obstetrics and Gynecology, Department of Surgery, New European Surgical Academy, Emory University, USA, E-mail: matevona@shu.edu; obgynvienna@myway.com

Rec date: May 16, 2016; Acc date: June 30, 2016; Pub date: July 7, 2016

Copyright: (C) 2016 Matevosyan NR. This is an open-access article distributed under the terms of the Creative Commons Attribution License, which permits unrestricted use, distribution, and reproduction in any medium, provided the original author and source are credited.

Citation: Matevosyan NR. Zika Virus and Perinatal Outcomes: Beyond the Myth. Crit Care Obst\&Gyne. 2016, 2:18.

\section{Abstract}

The World Health Organization defines current outbreak of Zika infection as a Public Health Emergency of International Concern (PHEIC). An attempt was made to contribute in a comprehensive screening protocol for ZIKV in pregnancy, based on systematic assessment of the empirical data. A total of 34 published articles, conferring to the level I-IIA evidence, are randomly identified to inform clinical, immunology, imaging, and patho-histology findings from 8,389 singleton pregnancies. Results of a comparative analysis between the Zika-positive and Zikanegative pregnant women presented with macopapular rash suggest that active Zika virus infection is predictive to the adverse perinatal outcomes: prematurity, fetal growth restriction, microcephaly, and Guillain-Barré syndrome. Temporal analysis between the viral peak lags, the first acute rash in women, and perinatal outcomes, support such associations.

Keywords: Zika virus; Flavivirus; Microcephaly; GuillainBarre syndrome; White brain damage

\section{Introduction}

Outbreaks of a mosquito-borne flavivirus, known as Zika virus (ZIKV), are consistently described in South America [1-8], Puerto Rico [9], French Polynesia [10-13], Southeast Asia [14-16], Federated States of Micronesia [17,18], and other parts of Oceania $[19,20]$. Present in Africa and Asia decades ago, the ZIKV infection is currently moving to South and Central America. It is anticipated, that Zika virus will spread to all other countries in the Americas that have dengue carrying Aedes mosquitoes-that is, all except Canada and Chile [21].

Based on reported clusters of microcephaly, cerebellar hypoplasia, and Guillain-Barré syndrome in neonates born to the ZIKV-affected mothers [6,7,13,22-25], the World Health Organization defines Zika infection as a Public Health Emergency of International Concern (PHEIC) [8,26-28].

Yet, vertical transmission of ZIKV remains ambiguous. Unlike other arboviral and tourism infections such as dengue (DEN), chikungunya (CHIK), West Nile virus (WNV), St. Louis encephalitis (SLE), or La Crosse encephalitis (LAS), Zika infection causes a fairly mild fever, headache, arthralgia, myalgia, and rarely does it manifest in maculopapular rash, acute exanthematous illness, or conjunctivitis. About the $80 \%$ of persons infected with ZIKV are asymptomatic and the fatality is thought to be rare [8,29-32]. Evolving findings suggest a presence of Zika virus in semen, a significant challenge to be addressed in seek of better understanding of teratogenicity and congenital anomalies [33].

\section{Aim}

To contribute in a comprehensive screening and diagnostic protocol for ZIKV in pregnancy, based on systematic assessment of the existing empirical data.

\section{Sampling}

A total of 34 published articles, conferring to the level I-IIA evidence, are randomly identified in research portals to inform clinical (obstetrical, neurological), serology, imaging, and patho-histology findings from 8,389 Zika-affected pregnancies.

\section{Inclusion criteria}

Rash and singleton pregnancies.

\section{Exclusion criteria}

- Pregnancies with twins or multitons;

- Pregnancies with uterine fibroids;

- Severe preeclampsia;

- Familial history of congenital anomalies;

- Prior infections with cytomegalovirus, rubella, dengue, toxoplasma gondii, parvovirus B19;

- History of habitual miscarriages, stillbirth, and perinatal death;

- Familial history of microcephaly;

- Alcohol or illicit drug use during pregnancy.

Clinical (observational) data include: miscarriage, stillbirth, fetal growth restriction (FGR), oligohydramnios, preeclampsia, preterm birth, small for gestational age (SGA) newborns, placentation defects (premature detachment, accreta, increta, 
percreta), neonatal conjunctivitis, neonatal pneumonia, microcephaly, splenomegaly, Guillain-Barré syndrome, congenital birth defects, and perinatal death. Serology data are generated from the reported results of reverse transcriptionpolymerase chain reaction (RT-PCR), immunoglobulin M (IgM) quantitative testing, and enzyme-linked immunosorbent assay (ELISA). Imaging data include the results of ultrasound, computed tomography (CT), and magnetic resonance imaging

(MRI) from the abdominal, thoracic, and cranial screening of the newborns. Pathological data include placental histology and neonatal autopsy results.

\section{Definitions}

Assessments of the clinical properties in reported studies are in compliance with the following definitions (Table 1).

Table 1 Assessments of the clinical properties in reported studies.

\begin{tabular}{|c|c|c|}
\hline Term & Definition & Source \\
\hline $\begin{array}{l}\text { Asymmetric fetal growth } \\
\text { restriction }\end{array}$ & $\begin{array}{l}\text { Fetus with an estimated weight below the } 10 \text { th percentile for gestation age, } \\
\text { with femur-length }(\mathrm{FL}) / \text { abdominal-circumference }(\mathrm{AC}) \text { greater than } 23.5 \text {, with } \\
\text { restriction of the fetal weight followed by length, while the head continues to } \\
\text { grow at normal rates (head sparing). }\end{array}$ & $\begin{array}{l}\text { American College of Obstetrics and } \\
\text { Gynecology (ACOG); Royal College of } \\
\text { Obstetricians and Gynecologists (RCOG) }\end{array}$ \\
\hline Symmetric fetal growth restriction & $\begin{array}{l}\text { Fetus with an estimated weight below the } 10 \text { th percentile for gestation age, } \\
\text { with FL/AC greater than } 23.5 \text {, and with the cranial circumference in } \\
\text { proportion to the rest of the body. }\end{array}$ & ACOG, RCOG \\
\hline $\begin{array}{l}\text { Growth-adjusted sonographic } \\
\text { age (GASA) }\end{array}$ & $\begin{array}{l}\text { GASA is estimated by ultrasound measurements of crown-rump length, } \\
\text { BPD, FL, and AC. }\end{array}$ & ACOG, RCOG \\
\hline Ponderal index (PI) & $\begin{array}{l}\text { A ratio of the fetal body weight to the length. } \\
\mathrm{PI}=[\text { weight } \times 100] \div[\text { length }] \text {. }\end{array}$ & The World Health Org (WHO) \\
\hline Doppler-shifted frequency (Fd) & $\begin{array}{l}\text { Fd depends on the angle of the ultrasound beam relative to the direction/ } \\
\text { angle of the bl } \\
\text { odd flow }(\Theta) \text {, frequency of the initial sound (Fo), velocity of the flow }(\mathrm{V}) \text {, and } \\
\text { speed of the sound in the tissue (commonly, } 1540 \mathrm{~m} / \mathrm{sec}) \\
\mathrm{Fd}=\mathrm{V}(2 \mathrm{Fo} \cos \Theta) \div \mathrm{C}\end{array}$ & lams et al. [35] \\
\hline Amniotic fluid index & $\begin{array}{l}\text { A pocket of amniotic fluid that measures at least } 1 \mathrm{~cm} \text { in two perpendicular } \\
\text { planes. Scores } 0-10 \text {. }\end{array}$ & lams et al. [35] \\
\hline Biparietal diameter (BPD) & $\begin{array}{l}\text { The transverse distance between the eminences of the two parietal bones of } \\
\text { fetal skull. }\end{array}$ & WHO \\
\hline Occipito-frontal diameter(OFD) & $\begin{array}{l}\text { The diameter of the fetal head from the external occipital protuberance to } \\
\text { the most prominent point of the frontal bone in the midline. }\end{array}$ & WHO \\
\hline Microcephaly & $\begin{array}{l}\text { Fetal/neonate head circumference at least } 2 S D \text { below the average } \\
\text { circumference size for age, sex, race, and gestation week. }\end{array}$ & Mayo Clinic Foundation \\
\hline Guillain-Barré syndrome & $\begin{array}{l}\text { An acute form of polyneuritis, often preceded by a respiratory infection, } \\
\text { causing weakness and often paralysis of the limbs. }\end{array}$ & WHO, Mayo Clinic Foundation \\
\hline Preeclampsia & $\begin{array}{l}\text { Diastolic blood pressure increased to } 15 \mathrm{mmHg} \text {, on two occasions, at least } 6 \\
\text { hours apart-with a difference }>5 \mathrm{mmHg} \text { between the arms; proteinuria } \\
\text { (presence of } 0.3 \mathrm{~g} \text { protein in } 24-\mathrm{h} \text { urine specimen on two random samples } \\
\text { collected at least } 4 \text { hours apart), and HELLP syndrome-all occurring after } \\
20 \text { gestation weeks. }\end{array}$ & ACOG \\
\hline Preterm birth & $\begin{array}{l}\text { Delivery of an infant from } 23 \mathrm{rd} \text { to } 37 \text { th weeks of gestation, which } \\
\text { approximates an average fetal weight from } 500 \text { to } 2500 \mathrm{~g} \text {, and height from } \\
28 \text { to } 48 \mathrm{~cm} \text {. }\end{array}$ & WHO \\
\hline Perinatal death & $\begin{array}{l}\text { Death of fetus (or neonate) weighing } 500 \text { grams or more and with height of } \\
28 \mathrm{~cm} \text { and more in the period between the } 22 \mathrm{nd} \text { gestation week to the } 7 \text { th } \\
\text { neonatal day. }\end{array}$ & ACOG, RCOG, WHO \\
\hline Odds & $\begin{array}{l}\text { The ratio of probability of the outcome to the probability of not having the } \\
\text { outcome: } p /(1-p) \text {. }\end{array}$ & Fletcher et al. [36] \\
\hline Odds ratio (OR) & $\begin{array}{l}\text { A comparison of event rates between exposed and unexposed groups, } \\
\text { calculated using odds instead of probabilities. }\end{array}$ & Fletcher et al. [36] \\
\hline Relative risk reduction (RR) & $\begin{array}{l}\text { The percentage of diseases prevented by a treatment: RRR }=\text { (risk in } \\
\text { unexposed-risk in exposed)/ risk in unexposed }\end{array}$ & Fletcher et al. [36] \\
\hline
\end{tabular}




\section{Data Extraction}

Frequencies and means extracted from the studies are combined to present weighted mean difference statistic and are modeled as measurable outcomes. Odds of numerical variables (biparietal diameter [BPD], femur length [FL], occipito-mental diameter [OMD], occipito-frontal diameter [OFD], sub-occipito-bregmatic diameter [SOBD], sub-mentobregmatic diameter [SMBD], amniotic fluid index [AFI], Apgar scores) are used as linear functions exposed to the factors. Temporal correlations and time lags are tested to distinguish the primary and recurrent infections, also to identify the proximity between the epidemic curves and reported clinical and parametric outcomes.

\section{Data Analysis}

Calculations use births as units of analysis. One-way analysis of variance (ANOVA) is used for the continuous data. KruskalWallis ANOVA is used for the ranked ordinal data. For binary variables relative risk (RR) and its $95 \%$ confidence interval $(\mathrm{Cl})$ are computed on an intention to treat basis. For multivariate models for scored outcomes, generalized estimating equations are used with a canonical correlation structure (for continuous variables), recursive partitioning (for dichotomous variables), and discriminant analysis (for both).

Table 2 Clinical and Parametric Properties of the Sample.

\begin{tabular}{|c|c|c|c|c|}
\hline Several properties of singleton pregnancies & $\begin{array}{l}\text { Zika-positive } \\
\text { women }\end{array}$ & $\begin{array}{l}\text { Zika-negative } \\
\text { women }\end{array}$ & $\begin{array}{l}\text { OR or RR } \\
(95 \% \text { Cl) }\end{array}$ & $\begin{array}{l}t \text { test } T(P) \text { or } \\
\text { test for trend } \times 2(P)\end{array}$ \\
\hline Sample size & 6275 & 2114 & & \\
\hline Tobacco smoking in pregnancy $(\%)$ & 0 & 1.2 & - & - \\
\hline History (or presence) of dengue (\%) & 31.4 & 56.2 & 0.5 & 0.08 \\
\hline Gestation age of ZIKV-exposure [M (range)] & $20(11-37)$ & $17(14-41)$ & 1.2 & 0.3 \\
\hline Fever $(\%)$ & 28 & 23.4 & 1.2 & 0.5 \\
\hline Headache $(\%)$ & 62.5 & 58.1 & 1.1 & 0.3 \\
\hline Myalgia (\%) & 74 & 38.4 & 1.9 & 0.05 \\
\hline Arthralgia (\%) & 65 & 41 & 1.6 & 0.16 \\
\hline Conjunctivitis in women (\%) & 58 & 19 & 3.1 & $0 . .002$ \\
\hline Retro-orbital pain (\%) & 49.3 & 31.4 & 1.6 & 0.25 \\
\hline Photophobia (\%) & 23.7 & 32.5 & 0.7 & 0.5 \\
\hline Descending macular rash (\%) & 51.4 & 50 & 1.02 & 0.8 \\
\hline Macopapular rash (\%) & 44 & 12 & 3.7 & $0 . .005$ \\
\hline Pruritus (\%) & 94 & 72 & 1.3 & 0.04 \\
\hline Lymphadenopathy (\%) & 40.5 & 6.5 & 6.2 & 0.02 \\
\hline Paresthesia (\%) & 46.6 & 40 & 1.2 & 0.8 \\
\hline Asymmetric fetal growth restriction (\%) & 5.8 & 4.9 & 1.2 & 0.01 \\
\hline
\end{tabular}




\begin{tabular}{|c|c|c|c|c|}
\hline Symmetric fetal growth restriction (\%) & 17.5 & 3.4 & 5.1 & $0 . .005$ \\
\hline Fetal anomalies detected by Doppler scan (\%) & 27.2 & 5 & 5.4 & 0.02 \\
\hline Neonate anomalies confirmed after birth (\%) & 13.6 & 4 & 3.3 & $0 . .005$ \\
\hline Oligohydramnios (\%) & 8 & 2.35 & 3.4 & 0.01 \\
\hline Amniotic fluid index (AFI) (M/SD) & $4.4(2.1-7.3)$ & $6.2(2.8-9.1)$ & 0.7 & 0.8 \\
\hline Preeclampsia (\%) & 35.9 & 25 & 1.4 & 0.03 \\
\hline Trombocytopenia (\%) & 1.3 & 0 & - & - \\
\hline Premature birth (\%) & 48.5 & 12.9 & 3.8 & 0.5 \\
\hline Perinatal death $(\%)$ & $2.3+1$ & 0 & - & - \\
\hline Conjunctivitis in newborns (\%) & 7.9 & 2.3 & 3.4 & 0.02 \\
\hline Rash in newborns (\%) & 7.9 & 3.4 & 2.3 & 0.02 \\
\hline Guillain-Barré syndrome (\%) & 11.5 & 2.3 & 5 & 0.01 \\
\hline Microcephaly (\%) & 8.75 & 1.2 & 7.3 & 0.02 \\
\hline Ventricular calcification in the brain (\%) & 8.6 & 2.1 & 4.1 & 0.05 \\
\hline Chronic placentitis (\%) & 89.3 & 46.7 & 1.9 & $0 . .002$ \\
\hline $\begin{array}{l}P \text { values are calculated with Fisher's exact test (tw } \\
P \text { values for ranging variables are calculated with th } \\
\text { Cronbach's alpha (ranging } 0.526-0.749 \text { ) proves th }\end{array}$ & $\begin{array}{l}\text { xcept as other } \\
\text { ndependent-sa } \\
\text { r-item clusters }\end{array}$ & $\begin{array}{l}\text { dian test. } \\
\text { arative. }\end{array}$ & & \\
\hline
\end{tabular}

The presented rates refer to the prevalence, not to the incidence, as a traditional meta-assessment cannot capture the temporal order of the events.

The first-impression descriptive data suggest that the ZIKVpositive women present significantly higher rates of conjunctivitis (RR 3.1; at $95 \% \mathrm{Cl}$ and $\mathrm{p}<0.002$ ), macopapular rash ( $R R$ 3.7; $p<0.005$ ), local or regional lymphadenopathy ( $R R$ 6.2; $p<0.02$ ), symmetric and asymmetric types of fetal growth restriction (RR 5.1 and 5.4 correspondingly, $p<0.02$ ), and oligohydramnios ( $R R 3,4 ; p<0.01)$. Among the noted adverse perinatal outcomes associated with active ZIKV are premature birth (RR 3.8; $\mathrm{p}<0.5$ ), neonatal conjunctivitis (RR 3.4; $p<$ 0.02 ), Guillain-Barré syndrome (RR 5.0, $p<0.01$ ), microcephaly (RR 7.3; $p<0.02$ ), with ventricular calcification of the white brain matter (RR 4.1; $p<0.05)$. Neonatal anomalies, confirmed after birth, are more evident in ZIKV-positive group (RR 3.3; $p<$ 0.005). Interestingly, the chronic placentitis almost similar presentation in both ZIKV - positive and ZIKV - negative cases of women with descending macular and maculopapular rash.

Pearson queue reveals substantial associations between oligohydramnios and ventricular calcification of the white brain matter $(0.422, \mathrm{Cl} 95 \%)$, as well as between the macopapular rash and Guillain-Barré syndrome $(0.538, \mathrm{Cl}$ 95\%). Weak associations are established between the paresthesia in women and Guillain-Barré syndrome in newborns (0.189) with reliable Cohen's Kappa (>0.80). For other clinical and parametric components (retro-orbital pain, fever, arthro-myalgia, pruritis, chronic placentitis, preeclammpsia, premature birth), correlations fail to produce convincing associations.
Unlike other studies $[20,22,34]$, our findings do not prioritize pruritus and athromyalgia as predominating symptoms of the active ZIKV (RR $1.3-1.9$ ), nor they are seen as strongly associated with the most described adverse perinatal outcome, such as microcephaly ( $0.246, p<0.01)$.

Temporal associations between microcephaly and ZIKV counts are described in a few studies that explore transplacental transmission of ZIKV $[13,25]$. For each model variant, maximum likelihood estimates of model parameters are obtained with a simulated annealing algorithm. The likelihood ratio method is used to compare different peak models. For the small size clusters, the Akaike information criterion is utilized [35]. In sensitivity analysis, scenarios are explored in which the final attack rate is $50 \%, 60 \%, 70 \%$, or $80 \%$ and the weekly number of births is 60 or 100 , and the relative changes in estimates ranges from $20 \%$ to $33 \%$.

The viral proteins and viral RNA are identified in placenta, Hofbauer cells, intervillous spaces, as well in scattered foci of microcalcifications in the brain tissue of the newborns to mothers infected at different weeks of pregnancy. Number of Guillain-Barré syndrome cases peaked after a lag of 5-9 weeks from the first acute rash, and number of suspected cases of microcephaly peaked after a lag of 30-33 weeks from the onset of the acute rash; correspond to time of potential infections of pregnant mothers during the first trimester. Such findings support the association of Guillain-Barré syndrome and microcephaly with Zika virus infection, providing evidence for a temporal relationship between the arboviral infection during the first trimester and the poor perinatal outcomes. 


\section{Discussions}

The massive outbreak of the mosquito-borne Zika infection enables quantifying and prioritizing associations between Zika virus in pregnancy and adverse perinatal outcomes (microcephaly, Guillain-Barré syndrome, white brain damage in the newborn). Yet, given the challenges in ZIKV testing of pregnant women and neonates, case controlled studies (with exclusion of other viral infections) are required for more sensitive and specific diagnostics. Among other studylimitations, RT-PCR tests may not detect ZIKV RNA in a newborn who acquired ZIKV infection in utero if the period of viremia has passed.

Still controversial, the risk of microcephaly from Zika infection seems lower compared to that from other viral infections associated to birth defects (cytomegalovirus, rubella, parvovirus B19) [35-37]. However, the incidence of Zika virus in general population can be higher during the outbreaks (so too the risk to pregnant women) compared to that in cytomegalovirus [38], rubella, or parvovirus B19 $[38,39]$. The mosquito vector, as the vulnerable point for Zika virus transmission, is a possible explanation. The high risk of symmetric fetal growth restriction with microcephaly, identified in our study, reconfirms that Zika virus is a captious public health concern.

\section{Conclusions}

The comparative analysis between the ZIKV positive and ZIKV negative pregnant women exposed to the Zika virus outbreak and presented with macopapular rash supports that the active Zika virus infection is predictive to the adverse perinatal outcomes such as prematurity, fetal growth restriction, microcephaly, and Guillain-Barré syndrome. Temporal analysis between the viral peak lags, the first acute rash in women, and perinatal outcomes, support such associations.

\section{Reference}

1. Paploski IA, Prates AP, Cardoso CW (2016) Time lags between exanthematous illnesses attributed to Zika cirus, Guillain-Barré syndrome and microcephaly, Salvador, Brazil. Emergency Infectious Diseases 15: 22.

2. Rodriguez-Morales A (2015) Zika: the new arbovirus threat for Latin America. J Infect Dev Ctries 9: 684-685.

3. Saiz JC, Vazquez-Calvo A, Blazquez AB (2016) Zika Virus: the latest newcomer. Frontiers in Microbiology 7: 496.

4. Oehler E, Watrin L, Larre P (2014) Zika virus infection complicated by Guillain-Barre syndrome- case report, French Polynesia. Euro Surveillance 19.

5. Slavov SN, Otaguiri KK, Kashima S, Covas DT (2016) Overview of Zika virus (ZIKV) infection in regards to the Brazilian epidemic. Brazilian Journal of Medical and Biological Research 49: e5420.
6. Mlakar J, Korva M, Tul N (2016) Zika virus associated with microcephaly. The New England Journal of Medicine 374: 951-958.

7. Cauchemez S, Besnard M, Bompard P (2016) Association between Zika virus and microcephaly in French Polynesia, 2013-15: a retrospective study. The Lancet.

8. Peterson E, Wilson ME, Touch S (2016) Rapid spread of Zika virus in the Americas - Implications for public health preparedness for mass gatherings at the 2016 Brazil Olympic games. International Journal of Infectious Diseases 44: 11-15.

9. Dirlikov E, Ryff KR, Torres-Aponte J, Thomas DL (2016) Update: Ongoing Zika virus transmission - Puerto Rico, November 1, 2015-April 14, 2016. MMWR: Morbidity and Mortality Weekly Report 65: 451-455.

10. Brault AC, Bowen RA (2016) The development of small animal models for Zika virus vaccine efficacy testing and pathological assessment. American Journal of Tropical Medicine and Hygiene p: 16.

11. Musso D, Baud D, Gubler DJ (2016) Zika virus: what do we know ? Clinical Microbiology and Infection.

12. Sampathkumar P, Sanchez JL (2016) Zika virus in the Americas: A review for clinicians. Mayo Clinic Proceedings 91: 514-521.

13. Burnham K, Anderson D (2002) Model selection and multimodel inference: a practical information-theoretic approach, 2nd Ed. Springer-Verlag, New York, NY.

14. Hennessey MJ, Fischer M, Panella A (2016) Zika virus disease in travelers returning to the United States, 2010-2014. American Journal of Tropical Medicine and Hygiene 16.

15. Chen HL, Tang RB (2016) Why Zika virus infection has become a public health concern? Journal of the Chinese Medical Associatio 79: 174-178.

16. Wong SS, Poon RW, Wong SC (2016) Zika virus infectionthe next wave after dengue? Journal of the Formosan Medical Association 115: 226-242.

17. Messina JP, Kraemer MU, Brady OJ, Pigott DM, Shearer FM, et al. (2016) Mapping global environmental suitability for Zika virus. e-Life 5: e15272.

18. Korzeniewski K, Juszczak D, Zwolińska E (2016) Zika another threat on the epidemiological map of the world. International Maritime Health 67: 31-37.

19. Carod-Artal FJ (2016) Epidemiology and neurological complications of infection by the Zika virus: a new emerging neurotropic virus. Revista de Neurologia 62: 317-328.

20. Lazear HM, Diamond MS (2016) Zika virus: New clinical syndromes and its emergence in the Western Hemisphere. Journal of Virology 90: 4864-4875.

21. Torjesen I (2016) Zika virus outbreaks prompt warnings to pregnant women. BMJ pp: 352. 
22. Brasil P, Pereira JP, Gabaglia CR (2016) Zika virus infection in pregnant women in Rio de Janeiro: Preliminary report. The New England Journal of Medicine.

23. Calvet G, Renato S, Aguiar RS, Melo AS (2016) Detection and sequencing of Zika virus from amniotic fluid of fetuses with microcephaly in Brazil: a case study. The Lancet Infectious diseases.

24. Besnard M, Lastere S, Teissier A (2014) Evidence of perinatal transmission of Zika virus, French Polynesia, December 2013 and February 2014. Euro Surveillance: 19.

25. Noronha L, Zanluca C, Azevedo ML (2016) Zika virus damages the human placental barrier and presents marked fetal neurotropism. Memorias do Instituto Oswaldo Cruz.

26. Heymann DL, Hodgson A, Alpha Sall A, et al. (2016) Zika virus and microcephaly: why is this situation a PHEIC? The Lancet 387: 719-721.

27. Picone O, Vauloup-Fellous C, D'Ortenzio E (2016) Zika virus infection during pregnancy. J Gynecol Obstet Biol Reprod 45: 415-423.

28. Gulland A (2016) Zika virus is a global public health emergency, declares WHO. BMJ 352: i657.

29. Centers for Disease Control and Prevention (2016) Zika virus symptoms, diagnosis, and treatment.

30. McCarthy M (2016) Zika virus was transmitted by sexual contact in Texas, health officials report. BMJ 352: i720.

31. Sarno M, Sacramento GA, Khouri R (2016) Zika virus infection and stillbirths: A case of hydrops fetalis, hydranencephaly and fetal demise. PLOS Epub Ahead of Print.

32. Rubin EJ, Greene MF, Baden LR (2016) Zika virus and microcephaly. The New England Journal of Medicine 374: 984-985.

33. Mansuy JM, Dutertre M, Mengelle C (2016) Zika virus: high infectious viral load in semen, a new sexually transmitted pathogen. The Lancet Infectious diseases.

34. Freitas BP, Oliveira Dias JF, Prazeres J (2016) Ocular findings in infants with microcephaly associated with presumed Zika virus congenital infection in Salvador, Brazil. The JAMA.

35. Naing ZW, Scott GM, Shand A (2016) Congenital cytomegalovirus infection in pregnancy: a review of prevalence, clinical features, diagnosis and prevention. Aust N Z J Obstet Gynaecol 56: 9-18.

36. De Santis M, Cavaliere AF, Straface G, Caruso A (2006) Rubella infection in pregnancy. Reproductive Toxicology 21: 390-398.

37. Silasi M, Cardenas I, Kwon JY (2015) Viral infections during pregnancy. The American Journal of Reproductive Immunology 73: 199-213.

38. Vauloup-Fellous C, Bouthry E, Grangeot-Keros L (2013) Infections materno-foetales: diffi cultés diganostiques et prise en charge maternelle. Ann Biol Clin 71: 5-18.

39. de Jong EP, Walther FJ, Kroes AC, Oepkes D (2011) Parvovirus B19 infection in pregnancy: new insights and management. Prenatal Diagnostics 31: 419-425. 